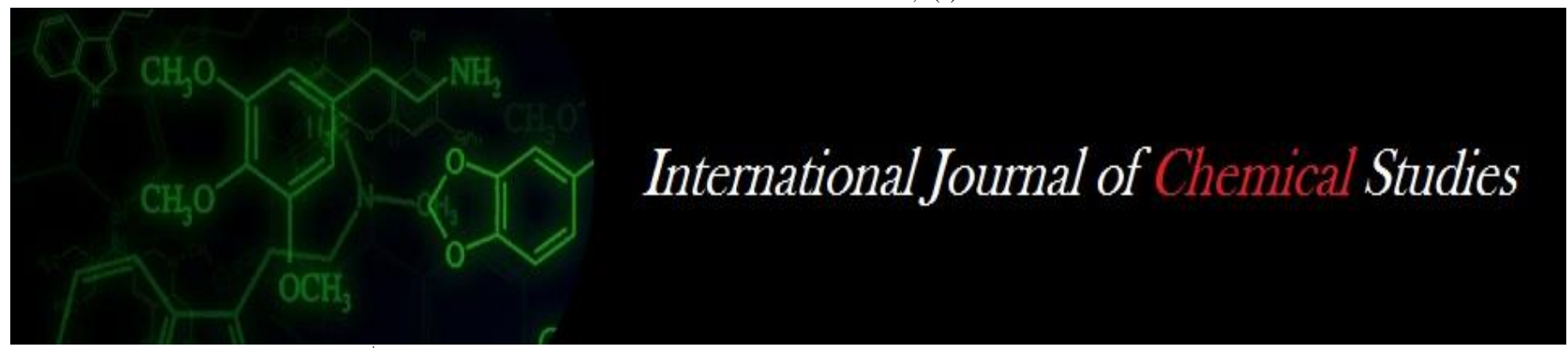

P-ISSN: 2349-8528

E-ISSN: 2321-4902

www.chemijournal.com

IJCS 2020; 8(3): 2906-2908

(C) 2020 IJCS

Received: 20-03-2020

Accepted: 22-04-2020

\section{P Vidyashree}

Department of Plant Pathology,

University of Agricultural

Sciences, College of Agriculture,

Raichur, Karnataka, India

\section{ST Yenjerappa}

Department of Plant Pathology,

University of Agricultural

Sciences, College of Agriculture,

Raichur, Karnataka, India

\section{Pramesh}

Department of Plant Pathology, University of Agricultural

Sciences, College of Agriculture,

Raichur, Karnataka, India

\section{Gururaj Sunkad}

Department of Plant Pathology, University of Agricultural

Sciences, College of Agriculture,

Raichur, Karnataka, India

Vikas Kulkarni

AICRP on Sunflower, Main

Agricultural Research Station,

University of Agricultural

Sciences, College of Agriculture,

Raichur, Karnataka, India
Corresponding Author:

$P$ Vidyashree

Department of Plant Pathology,

University of Agricultural

Sciences, College of Agriculture,

Raichur, Karnataka, India

\section{Present status of Alternaria leaf blight disease of sunflower in north eastern Karnataka}

\author{
P Vidyashree, ST Yenjerappa, D Pramesh, Gururaj Sunkad and Vikas \\ Kulkarni
}

DOI: https://doi.org/10.22271/chemi.2020.v8.i3ap.9654

\begin{abstract}
Sunflower is one of the most important edible oilseed crops in India. Among the major diseases of sunflower, Alternaria leaf blight caused by Alternaria helianthi (Hansf.) Tubaki and Nishihara is most devastating disease in Karnataka. A roving survey was conducted to assess the severity of Alternaria leaf blight during Kharif season 2018 in Raichur, Ballari, Koppal and Gulbarga districts of North Eastern Karnataka. The survey results revealed that disease severity was noticed in all locations surveyed with a range of 13.33 to 65.60 per cent. Maximum disease severity was observed in Koppal district (45.34\%) and least severity was noticed in Kalburgi district (22.43\%).
\end{abstract}

Keywords: survey, sunflower, Alternaria leaf blight, severity

\section{Introduction}

Sunflower (Helianthus annus) is one of the important oilseed crops in India, popularly known as "Surajmukhi" which belongs to the botanical family "Compositae". It was originated in North America. Sunflower is a major source of vegetable oil in the world, which contains about 39 to 49 per cent oil in the seed. It ranks second to soybean in worldwide vegetable oil production. It is a richest source of linoleic acid which is good for heart patients. Leaf blight caused by Alternaria helianthi is the most devastating disease in Karnataka. The disease is known to cause more than 80 per cent of yield loss under severe epiphytotic conditions in Northern Karnataka (Shankergoud et al., 2006) ${ }^{[11]}$.

Hansford (1943) first reported the fungus causing leaf spot of sunflower from Uganda and described the causal organism as Helminthosporium helianthi. Tubaki and Nishihara (1969) ${ }^{[12]}$ isolated this fungus from diseased leaves of cultivated sunflower crop and confirmed causal organism as A. helianthi. First record of this disease in India was simultaneously reported by Narain and Saksena (1973) ${ }^{[9]}$; Kolte and Mukhopadhyay (1973) [5] from Uttar Pradesh; Anilkumar et al. (1974) ${ }^{[1]}$ reported this disease from Karnataka.

This disease has been reported from different parts of the world including India and is known to cause reduction in flower size, number of seeds per head, seed yield per plant, test weight and also oil content (Balasubramanyam and Kolte, 1980) ${ }^{[2]}$. The loss in yield varies from 11.30 to 73.33 per cent depending on the extent of infection and crop stage of infestation (Reddy and Gupta, 1977) [10]. In India, the disease appears in the states of Karnataka, Maharashtra, Bihar, Andhra Pradesh, Haryana and Tamil Nadu. In Karnataka, the disease occurred in epidemic form in 1987, with a disease severity of 95 to 100 per cent (Hiremath et al., 1990) ${ }^{[4]}$. In these areas, yield losses may range from 15 to 90 per cent, with oil losses from 20 to 30 per cent. Alternaria is reported to cause losses from 50-60 per cent in more humid areas.

\section{Material and Methods}

A roving survey for severity of Alternaria leaf blight in sunflower was taken in major sunflower growing areas during Kharif 2018 in two taluks of Raichur, three taluks of Koppal, two taluks of Ballari and four taluks of Kulbargi. In each taluka, minimum of three villages were selected and in each village three farmers fields and in each field five spots were selected per acre to assess the severity of the disease. The survey was carried during star bud to 
harvesting stage. Per cent severity of the disease was recorded in each field and averaged for each village.

Scoring of the disease was done in field by using 0-9 scale given by Mayee and Datar (1986) ${ }^{[7]}$.

Disease rating scale of Alternaria leaf blight of sunflower

\begin{tabular}{|c|c|c|}
\hline Grade & Disease description & Disease reaction \\
\hline 0 & No symptoms on the leaf & Immune \\
\hline 1 & 1 per cent or less of the area infected & Highly resistant \\
\hline 3 & $1-10$ per cent of leaf area infected & Resistant \\
\hline 5 & $11-25$ per cent of leaf area infected & Moderately resistant \\
\hline 7 & $26-50$ per cent of the leaf area infected & Susceptible \\
\hline 9 & $\begin{array}{c}\text { More than } 50 \text { per cent or more leaf } \\
\text { area infected }\end{array}$ & Highly susceptible \\
\hline
\end{tabular}

The per cent disease index (PDI) was calculated by using the formula given by Wheeler (1969).

PDI $(\%)=\frac{\text { Summation of all numerical ratings }}{\text { Total number of leaves scored } \mathrm{x} \text { maximum rating scale observed }} \times 100$

\section{Results and Discussion}

The total surveyed villages of four districts reported that maximum disease severity of 65.60 per cent was observed in Banahalli village of Koppal taluk and minimum disease severity of 13.33 per cent was observed in Yadrami village of Jewargi taluk. The village-wise disease severity has been presented in Table 1.

In Raichur district highest disease severity of 40.50 per cent was recorded in Hirekotnal, followed by Tappaladoddi with severity of 38.30 per cent and least disease severity of 20.50 per cent was observed in Bandisunkapur village. In Koppal district highest disease severity was observed in Banahalli with 65.60 per cent, followed by Alavandi village with disease severity of 63.00 per cent while minimum disease severity of 15.50 per cent was obtained in Hosur village. In Bellari district maximum disease severity of 43.55 per cent was recorded in Itagi village followed by Gaddikere with 42.20 per cent and minimum disease severity was observed in Morigere with 36.93 per cent. In Kalburgi district maximum disease severity was observed in Melkunda with 33.55 per cent followed by Hadagil with disease severity of 30.33 per cent and minimum disease severity of 13.33 per cent was observed in Yadrami village.

The major sunflower growing areas of North Eastern Karnataka surveyed shows that, maximum PDI of 45.34 per cent was observed in Koppal followed by Ballari district with disease severity of 40.46 per cent and minimum mean district disease severity of 22.43 was observed in Kalburgi district. Further, among all the taluks of four districts shows that maximum disease severity of 57.30 per cent was observed in Koppal taluk of Koppal district and minimum disease severity of 16.34 per cent was observed in Aland taluk of Kalburgi district (Table 2).

The results confirmed with earlier reports of Mesta et al.
(2009) ${ }^{[8]}$ conducted survey during 2004 to 2006 in North Karnataka districts and reported that Alternaria leaf blight disease was ranges from 13.10 per cent to 45.60 per cent in sunflower crop. The maximum disease severity of 45.60 per cent was observed in Bagalkot taluk due to high rainfall with $384 \mathrm{~mm}$ was major factor for development of high amount of disease in Bagalkot taluk compared to the other taluks of Northern Karnataka where as minimum rainfall of $373 \mathrm{~mm}$ and disease severity of 30.10 per cent was recorded in Lingasugur taluk. It indicates rainfall is important weather factor to obtain high Alternaria leaf blight disease in sunflower crop.

Koppal district shows maximum disease severity of Alternaria leaf blight in Kharif 2018 which was due to uneven rainfall with more relative humidity had built up, higher inoculum level and it was agreement with the results of Kolte (1984) [6] as reported that, higher rainfall and relative humidity to cause severe epidemics of Alternaria leaf blight of sunflower. In Koppal district, farmers usually do not practice fungicidal spray against Alternaria leaf blight of sunflower and flooded irrigation may also favor for the development of disease in sunflower.

The lowest disease severity of 16.34 was observed in Aland taluk of Kalburgi district due to growing of Kargil 413 hybrid lead to less susceptible for A. helianthi and rainfed practices without irrigation, where sunflower crop not grow continuously may also leads to minimum Alternaria leaf blight disease in sunflower crop. This results confirmed with the results of Chaube and Singh (2001) [3] reported that, continuous cultivation of any crop over the season and years will build up inoculum level and cause more disease, but in Aland taluk farmers did not grow sunflower crop continuously over the season that shows lowest disease severity in sunflower. It indicates monocropping carry disease inoculum from season to season but rotating the crops can be avoid the infection of $A$. helianthi in sunflower crop.

The Alternaria leaf blight disease severity varied from one locality to another, due to prevailing varied environmental conditions, cropping pattern and amount of inoculum build up in susceptible cultivars of sunflower crop to cause more disease severity in the farmer's field. The sunflower was cultivated in three season viz., Kharif, rabi and summer which was recorded during 2018 survey and there is no definite sowing date for sunflower crop. This not only exhausts the nutrients from the soil but also paves the way for continuous survivability of the pathogen. The infected debris left in the field serve as major source of infection, thus causing epidemic throughout the season. Crop stage was also found to be closely related to disease severity and the susceptibility increases with increase in age of the crop and cause more disease severity in sunflower where the stage of crop was at maturity and harvesting time than compared to flowering stage.

Table 1: Prevalence of Alternaria leaf blight of sunflower in different districts of North Eastern Karnataka during Kharif 2018

\begin{tabular}{|c|c|c|c|c|c|c|c|c|}
\hline Sl. No. & District & Talukas & Villages & Soil type & Variety & Stage of the crop & Irrigated/Rainfed & PDI (\%) \\
\hline \multirow{8}{*}{1} & \multirow{8}{*}{ Raichur } & \multirow{4}{*}{ Manvi } & Hirekotnal & Black soil & Kaveri & Maturity & Rainfed & 40.50 \\
\hline & & & Gudidini & Black soil & Kaveri & Maturity & Rainfed & 33.50 \\
\hline & & & Tappaladoddi & Black soil & Kaveri & Maturity & Rainfed & 38.30 \\
\hline & & & Chincharaki & Black soil & Kaveri & Maturity & Rainfed & 24.50 \\
\hline & & \multirow{4}{*}{ Lingasugur } & Hamminagadda & Red soil & LG hybrid & Maturity & Rainfed & 32.50 \\
\hline & & & Bommanahal & Red soil & LG hybrid & Maturity & Irrigated & 22.30 \\
\hline & & & AsihalTanda & Red soil & LG hybrid & Maturity & Rainfed & 21.50 \\
\hline & & & Bandisunkapur & Red soil & LG hybrid & Maturity & Rainfed & 20.50 \\
\hline 2 & Koppal & Koppal & Alavandi & Red soil & Kaveri & Maturity & Irrigated & 63.00 \\
\hline
\end{tabular}




\begin{tabular}{|c|c|c|c|c|c|c|c|c|}
\hline & & & Banahalli & Red soil & Kaveri & Harvesting & Irrigated & 65.60 \\
\hline & & & Bikanahalli & Red soil & Kaveri & Harvesting & Irrigated & 52.60 \\
\hline & & & Sindhogi & Red soil & Kaveri & Harvesting & Irrigated & 48.00 \\
\hline & & \multirow{4}{*}{ Kushtagi } & Nawalahalli & Red soil & Kaveri & Harvesting & Rainfed & 44.50 \\
\hline & & & Gumgera & Red soil & Kaveri & Harvesting & Rainfed & 47.30 \\
\hline & & & Ganganala & Red soil & Kaveri & Harvesting & Rainfed & 50.60 \\
\hline & & & Hiremannapur & Red soil & Kaveri & Harvesting & Rainfed & 54.30 \\
\hline & & \multirow{3}{*}{ Yelburga } & Hirearlihalli & Red soil & Kaveri & Harvesting & Rainfed & 34.30 \\
\hline & & & Hosur & Red soil & Kaveri & Flowering & Rainfed & 15.50 \\
\hline & & & Yalburga & Red soil & Kaveri & Maturity & Rainfed & 38.90 \\
\hline \multirow{6}{*}{3} & \multirow{6}{*}{ Bellari } & \multirow{3}{*}{ Hadagali } & Holgundi & Red soil & Kaveri & Maturity & Rainfed & 41.33 \\
\hline & & & Itagi & Red soil & Kaveri & Maturity & Irrigated & 43.55 \\
\hline & & & Uttangi & Red soil & Kaveri & Maturity & Rainfed & 39.27 \\
\hline & & \multirow{3}{*}{ Hagaribommanahalli } & Gaddikere & Red soil & Kaveri & Maturity & Rainfed & 42.20 \\
\hline & & & Morigere & Red soil & Kaveri & Maturity & Rainfed & 36.93 \\
\hline & & & Sonna & Red soil & Kaveri & Maturity & Rainfed & 39.50 \\
\hline \multirow{11}{*}{4} & \multirow{11}{*}{ Kalburgi } & \multirow{3}{*}{ Jewargi } & Andola & Black soil & Sunbred & Maturity & Rainfed & 15.55 \\
\hline & & & Yadrami & Black soil & Sunbred & Maturity & Rainfed & 13.33 \\
\hline & & & Kellur & Black soil & Sunbred & Maturity & Rainfed & 20.22 \\
\hline & & \multirow{3}{*}{ Kalburgi } & Bhimalli & Black soil & Sunbred & Maturity & Rainfed & 28.33 \\
\hline & & & Melkunda & Black soil & Sunbred & Maturity & Rainfed & 33.55 \\
\hline & & & Hadagil & Black soil & Sunbred & Maturity & Rainfed & 30.33 \\
\hline & & \multirow{2}{*}{ Chittapur } & Malkhed & Black soil & Kargil-413 & Maturity & Rainfed & 24.10 \\
\hline & & & Dandothi & Black soil & Kargil-413 & Maturity & Rainfed & 28.50 \\
\hline & & \multirow{3}{*}{ Aland } & Narona & Black soil & Kargil-413 & Maturity & Rainfed & 14.30 \\
\hline & & & Kadaganchi & Black soil & Kargil-413 & Maturity & Rainfed & 13.50 \\
\hline & & & Salagar & Black soil & Kargil-413 & Maturity & Rainfed & 21.22 \\
\hline
\end{tabular}

Table 2: Per cent disease index of Alternaria leaf blight of sunflower at survey in different districts and taluks of North Eastern Karnataka during Kharif 2018

\begin{tabular}{|c|c|c|c|c|}
\hline \multirow[t]{2}{*}{ Sl. No. } & \multirow[t]{2}{*}{ District } & \multirow[t]{2}{*}{ Taluk } & \multicolumn{2}{|c|}{$\begin{array}{c}\text { Mean per cent } \\
\text { disease index }(\%)\end{array}$} \\
\hline & & & Taluks & Districts \\
\hline \multirow{2}{*}{1} & \multirow{2}{*}{ Raichur } & Manvi & 34.20 & \multirow{2}{*}{29.2} \\
\hline & & Lingasugur & 24.20 & \\
\hline \multirow{3}{*}{2} & \multirow{3}{*}{ Koppal } & Koppal & 57.30 & \multirow{3}{*}{45.34} \\
\hline & & Kustagi & 49.17 & \\
\hline & & Yelburga & 29.56 & \\
\hline \multirow{2}{*}{3} & \multirow{2}{*}{ Ballari } & Hadagali & 41.38 & \multirow{2}{*}{40.46} \\
\hline & & Hagaribommanhalli & 39.54 & \\
\hline \multirow{4}{*}{4} & \multirow{4}{*}{ Kalburgi } & Jewargi & 16.36 & \multirow{4}{*}{22.43} \\
\hline & & Kalburgi & 30.73 & \\
\hline & & Chittapur & 26.30 & \\
\hline & & Aland & 16.34 & \\
\hline
\end{tabular}

\section{References}

1. Anilkumar TB, Urs SD, Seshadri VS, Hegde RK. Alternaria leaf spot of sunflower. Curr. Sci. 1974; 43:9394.

2. Balasubramanyam N, Kolte SJ, Effect of Alternaria blight on yield components, oil content and seed quality of sunflower. Indian J. Agric. Sci. 1980; 50:701-706.

3. Chaube HS, Singh R, Introductory Plant Pathology, International Book Distributing Company, Lucknow. 2001, p.132.

4. Hiremath PC, Kulkarni MS, Lokesh MS. An epiphytotic of Alternaria blight of sunflower in Karnataka. Karnataka J. Agric. Sci. 1990; 3:277-278.

5. Kolte SJ, Mukhopadhyay AN. Occurrence of some new sunflower disease in India. Pesticides Abstracts and News Summary. 1973; 19:392-396.

6. Kolte SJ. Diseases of annual edible oilseed crops. CRC Press, Florida. 1984; 3:9-96.

7. Mayee CD, Datar VV. Phytopathometry. Tech. Bull.-1, Marathwad Agric. Univ., Parbhani. 1986, p. 251.
8. Mesta RK, Benagi VI, Shankergoud I, Megeri N, Survey for the status of Alternaria blight of sunflower in Northern Karnataka. Karnataka J. Agric. Sci. 2009; 22 (5):1032-1037.

9. Narain A, Saksena HK. Occurrence of Alternaria leaf spot of sunflower in India. Indian J. Mycol. P1. Pathol. 1973; 3:115-116.

10. Reddy PC, Gupta BM. Disease loss appraisal due to leaf blight of sunflower incited by Alternaria helianthi. Indian Phytopathol. 1977; 30:569-570.

11. Shankergoud I, Shadakshari YG, Parameshwarappa KG, Chandranath HT, Katti P, Mesta RK. Sunflower and Castor research in Karnataka- An overview, Univ. Agric. Sci., Dharwad, 2006, pp. 1-41.

12. Tubaki K, Nishihara N. Alternaria helianthi (Hansf.) Comb. Nov. Trans. British Mycol. Soc. 1969; 53:147149. 